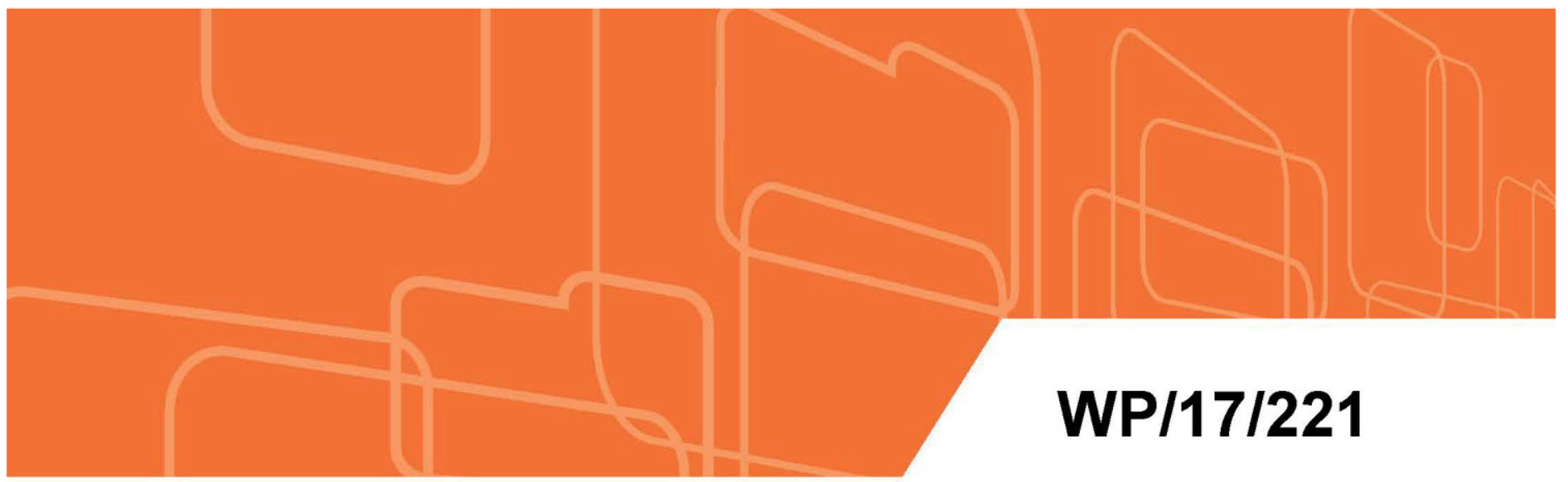

IMF Working Paper

\title{
State-Owned Enterprises in Emerging Europe: The Good, the Bad, and the Ugly
}

by Uwe Böwer

IMF Working Papers describe research in progress by the author(s) and are published to elicit comments and to encourage debate. The views expressed in IMF Working Papers are those of the author(s) and do not necessarily represent the views of the IMF, its Executive Board, or IMF management. 


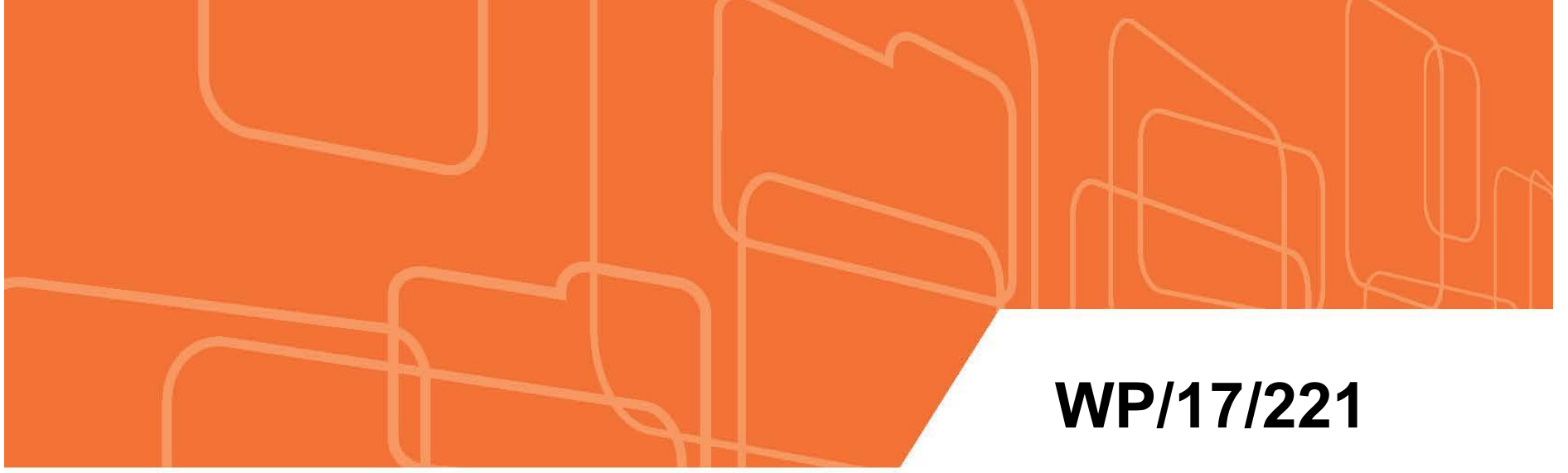

\section{IMF Working Paper}

\section{State-Owned Enterprises in Emerging Europe: The Good, the Bad, and the Ugly}

by Uwe Böwer

IMF Working Papers describe research in progress by the author(s) and are published to elicit comments and to encourage debate. The views expressed in IMF Working Papers are those of the author(s) and do not necessarily represent the views of the IMF, its Executive Board, or IMF management. 


\title{
IMF Working Paper
}

European Department

\section{State-Owned Enterprises in Emerging Europe: The Good, the Bad, and the Ugly \\ Prepared by Uwe Böwer ${ }^{1}$}

Authorized for distribution by Reza Baqir

October 2017

\begin{abstract}
IMF Working Papers describe research in progress by the author(s) and are published to elicit comments and to encourage debate. The views expressed in IMF Working Papers are those of the author(s) and do not necessarily represent the views of the IMF, its Executive Board, or IMF management.
\end{abstract}

\begin{abstract}
State-owned enterprises (SOEs) play an important role in Emerging Europe's economies, notably in the energy and transport sectors. Based on a new firm-level dataset, this paper reviews the SOE landscape, assesses SOE performance across countries and vis-à-vis private firms, and evaluates recent SOE governance reform experience in 11 Emerging European countries, as well as Sweden as a benchmark. Profitability and efficiency of resource allocation of SOEs lag those of private firms in most sectors, with substantial cross-country variation. Poor SOE performance raises three main risks: large and risky contingent liabilities could stretch public finances; sizeable state ownership of banks coupled with poor governance could threaten financial stability; and negative productivity spillovers could affect the economy at large. SOE governance frameworks are partly weak and should be strengthened along three lines: fleshing out a consistent ownership policy; giving teeth to financial oversight; and making SOE boards more professional.
\end{abstract}

JEL Classification Numbers: G38, H63, L33

Keywords: State-Owned Enterprises, Emerging Europe

Author’s E-Mail Address: UBoewer@imf.org

\footnotetext{
${ }^{1}$ I thank Reza Baqir, Brian Olden, and seminar participants in the IMF's European Department and Fiscal Affairs Department for providing helpful comments.
} 


\section{CONTENTS}



I. Introduction ..................................................................................................................................4

II. Stylized Facts........................................................................................................................................

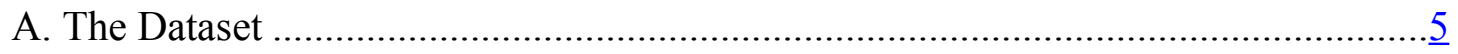

B. The Role of SOEs in the Economy …………………………………………...

III. SOE Performance and Economic Risks.........................................................................8

A. Profits/Losses and Liabilities .............................................................................

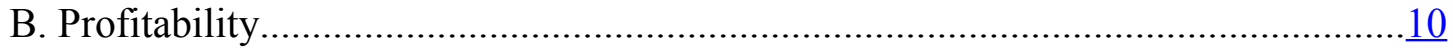

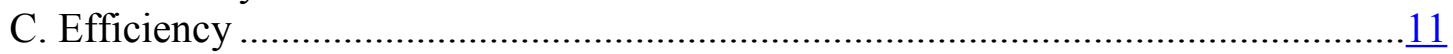

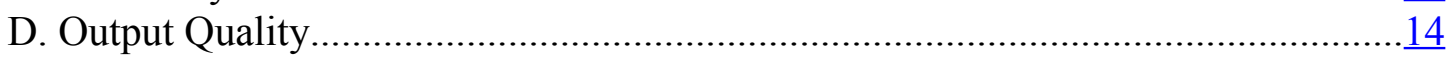

E. Economic Risks of Poor SOE Performance ……………………………………...15

IV. SOE Governance ..............................................................................................................16

A. An Ideal SOE Governance Framework …………………...............................16

B. SOE Governance Performance and Reforms in Emerging Europe...........................17



VI. Annex .............................................................................................................................................



\section{BOXES}

1. OECD Guidelines on Corporate Governance of SOEs...................................................17

\section{FIGURES}



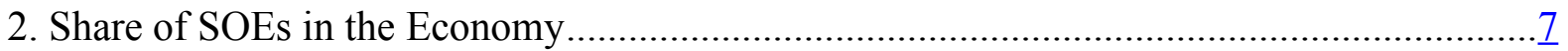

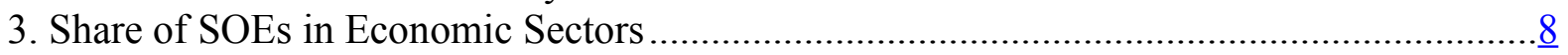

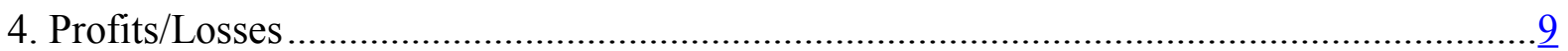

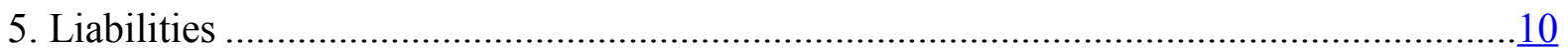

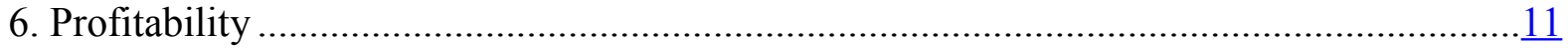



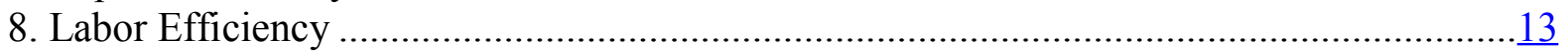



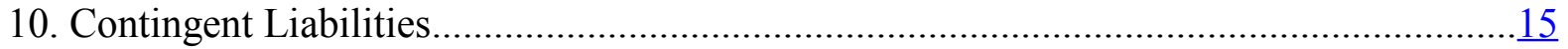

11. SOE Governance Performance ……………………................................................

12. SOE Governance Challenges in Emerging Europe …………........................................... 


\section{INTRODUCTION}

State-owned enterprises (SOEs) play an important role in the economies of Emerging Europe. Poorly exercised state ownership can carry substantive macroeconomic risks on fiscal policy, financial stability and, via productivity spillovers, on economic growth. Emerging European economies are particularly susceptible to these risks as, in some cases, legacy issues with SOEs prevail as a result of inconsistent privatization during the transition process. Varying degrees of institutional quality aggravate the risks of suboptimal SOE governance.

The objective of this paper is twofold. The first objective is to review the SOE landscape in Emerging Europe and assess SOE performance across countries and vis-à-vis private firms. A new firm-level dataset is constructed, covering 11 Emerging European countries and Sweden as a benchmark country. The second objective is to gauge the underlying SOE governance frameworks in these countries by identifying shortcomings, evaluating recent reform experiences, and drawing overall lessons for policy implications.

The analysis finds large variation in SOE performance and governance reforms across countries - "good, bad, and ugly". SOEs make up significant shares of employment and output in several countries. They are especially important in network sectors, such as energy, transportation, and water management. In some countries and sectors, SOE are heavily lossmaking. Large amounts of debt have been piled up in the energy and transport sectors, but partly also in telecoms, financial services and real estate. SOE profitability and the efficiency of resource allocation in SOEs largely lags those in private firms, and the gaps are particularly large in some of the Southeast European and Baltic countries. Risks arise where contingent liabilities are sizeable, poorly regulated state ownership of banks amplify financial instability, and negative productivity spillovers affect the larger economy. Underlying SOE governance reforms have advanced in Slovenia, Lithuania and Latvia but have remained rudimentary so far in Bulgaria.

The emerging lessons call for decisive SOE governance reform. First, a well-defined ownership policy is needed at the highest level, clarifying the rationale for state ownership and reviewing it case-by-case every year. Centralizing the ownership function, rather than leaving it with line ministries, is particularly advisable if the overall institutional quality is weak. Second, financial oversight teams need to have teeth to implement and monitor financial performance targets. Dividend policies should be balanced and predictable. Third, firm-level governance needs to ensure professionalized SOE boards. Appointments should be determined by skill and experience, not political affiliation. Remuneration needs to strike a healthy balance of remaining competitive while being transparent and merit-based.

The paper is organized as follows. Section II presents the dataset and sets the scene by reviewing the broader SOE landscape in Emerging Europe. Section III assesses SOE performance including indebtedness, profitability, efficiency and output quality. It also discusses risks of poor SOE performance on fiscal, financial, and macroeconomic stability. Section IV addresses SOE governance by setting out the ideal framework, identifying major challenges in Emerging Europe and, based on a country-by-country review, draws overarching lessons for policy implications. Section V concludes. 


\section{STYlized FACTS}

This section presents the SOE dataset and discusses the role of SOEs in Emerging Europe's economies. First, the presentation includes the overall number of SOEs across countries, as well as a disaggregation of SOEs into eight relevant economic sectors by country, highlighting the distribution by number of SOEs, employment, and output. Second, the output and employment shares of SOEs are presented by country, and then by sector and country, pointing to a dominant role of SOEs mainly in the network sectors of several countries.

\section{A. The Dataset}

The analysis of SOEs is based on a rich firm-level dataset. The dataset was constructed for this study and is based on the Orbis database provided by Bureau Van Dijk. It covers the years 2012-2014. Annual averages aim at smoothening the data. After cleaning for inactive companies, outliers and double entries, the total number of SOEs amounts 6,282. ${ }^{2}$ Although the coverage of the Orbis database is extensive, it cannot be regarded as fully exhaustive, so the presented aggregate figures of SOE activity should be understood as indicative. ${ }^{3}$

The dataset comprises eleven new European Union member states, ${ }^{4}$ as well as Sweden. The country choice is not only motivated by data limitations but also by comparability of countries which operate in the homogeneous economic and legal environment of the EU, e.g. regarding market access and state-aid scrutiny. Sweden is added as a benchmark country, representing an advanced economy which operates are large SOE portfolio with a very sound governance framework.

The number of SOEs varies across countries. While the dataset records 2097 SOEs for Poland, 1699 for Sweden, and around 800 each for Bulgaria and Romania, the numbers in other countries are far smaller. Beyond data coverage, this variation is likely due to different privatization strategies since the beginning of economic transition, as well as different organizational forms of municipal entities.

The SOE landscape is characterized by a large variety of firms. SOEs vary in size, from small local entities with only a few employees to large-scale companies, notably in the network industries. Breaking the dataset down into eight economic sectors which are most

\footnotetext{
${ }^{2}$ State ownership is defined as a minimum stake of 50.1 percent. The indicated numbers refer to the maximum available firm data. For several indicators reported in this paper, the actual availability of data varies by country and sector.

3 This paper adopts a wide definition of the term "SOE", including firms owned by the central government as well as sub-national government levels, classified within and outside of general government accounts.

${ }^{4}$ Bulgaria, Croatia, Czech Republic, Estonia, Hungary, Latvia, Lithuania, Poland, Romania, Slovakia, and Slovenia.
} 
relevant for SOE activity ${ }^{5}$ reveals differences between the relative shares in the firm numbers, employment, and output by sector. ${ }^{6}$ The number of SOEs is dominated by firms in healthcare, water utilities, services, and other industries. In terms of SOE employment, healthcare, transport, and postal services feature prominently in the dataset. However, output shares are more strongly dominated by the energy sector, alongside transport and other services. ${ }^{7}$

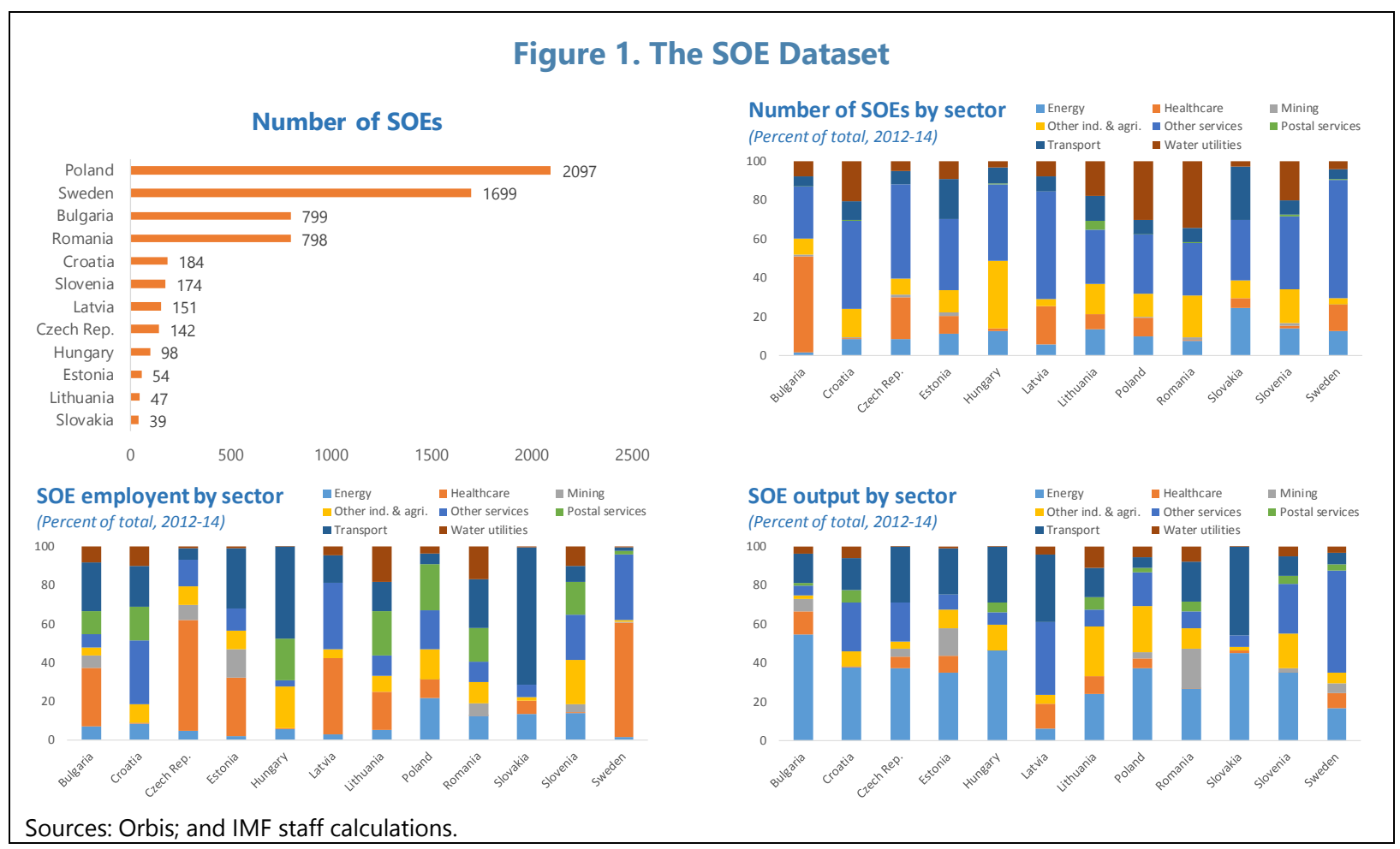

\footnotetext{
${ }^{5}$ Sectors are defined in line with NACE-2 sections as follows: Mining (B - mining \& quarrying), other industries \& agriculture (A - agriculture, $\mathrm{C}$ - manufacturing, F - construction), energy (D - electricity, gas, steam and air conditioning supply), water utilities ( $\mathrm{E}$ - water supply, sewerage, waste management and remediation activities), transport (H49-H52 - land, water and air transport and warehousing/support activities for transportation), postal services (H53 - postal and courier services), healthcare (Q - human health and social work activities), other services ( $\mathrm{G}$ - wholesale and retail trade, I - accommodation, J - ICT services, $\mathrm{K}$ financial services, $\mathrm{L}$ - real estate services, $\mathrm{M}$ - professional activities, $\mathrm{N}$ - administrative and support services, $\mathrm{P}$ - education, $\mathrm{R}$ - arts \& entertainment, $\mathrm{S}$ - other service activities).

${ }^{6}$ In addition to firm number, employment, and output, it was attempted to include value-added in this presentation, recognizing that output data tends to be biased by varying degrees of intermediate good inputs. However, data scarcity as well as the prevalence of negative values for value-added, on the back of negative profits, led to the exclusion of the constructed value-added indicator.

${ }^{7}$ Hospitals and medical centers account for around half of SOEs in Bulgaria as they are set up as trade companies since a healthcare reform in 2000. In other countries, the healthcare sector plays a far smaller role, or is completely absent from the SOE dataset. Given the atypical role of healthcare for SOE analysis, this sector is excluded from the remainder of the paper. The same applies for postal services which, despite partly sizable employment, contributes very little to the number of SOEs and SOE output.
} 


\section{B. The Role of SOEs in the Economy}

SOEs have an important economic role in several countries. Aggregating across all sectors, SOEs contribute between around 1 and 12 percent to total economic output, and between around 0.5 and 8 percent of total employment. Slovenia, Poland and Sweden exhibit the largest SOE output shares while large shares of SOE employment are found in Sweden, Bulgaria and Slovenia. The differences between output and employment shares suggest that some countries operate more capital-intensive production in SOE sectors while in other countries, laborintensive production is more prominent.

Figure 2. Share of SOEs in the Economy

Share of SOEs in the economy (Percent of total)

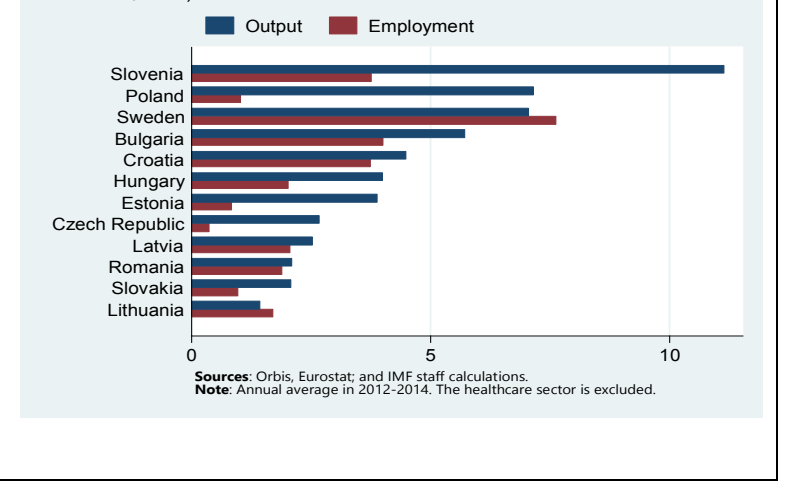

In the network industries of several countries, SOEs play a dominating role. Breaking down the output and employment shares of SOEs by sectors shows that the energy sector is most strongly dominated by SOEs. In Slovenia, Hungary, Poland, and Bulgaria, more than 60 percent of energy-sector output is generated by SOEs. The SOE employment shares are largely below the output shares, pointing to capital intensive production and the use of intermediate product inputs. The mining sectors of Sweden and Estonia are also clearly dominated by SOEs, with output shares exceeding 50 percent. In the water utility sector, SOEs are responsible for around 30 percent of output in Poland, Bulgaria, and Slovenia. The transport sector is most clearly influenced by SOEs in Hungary, with output and employment shares above 20 percent, and in Bulgaria with an employment share of around 26 percent, albeit with a lower output share. In other services, only Sweden and Slovenia exhibit SOE output shares of above 5 percent while in other industries, the influence of SOEs remains below 5 percent in all countries. 


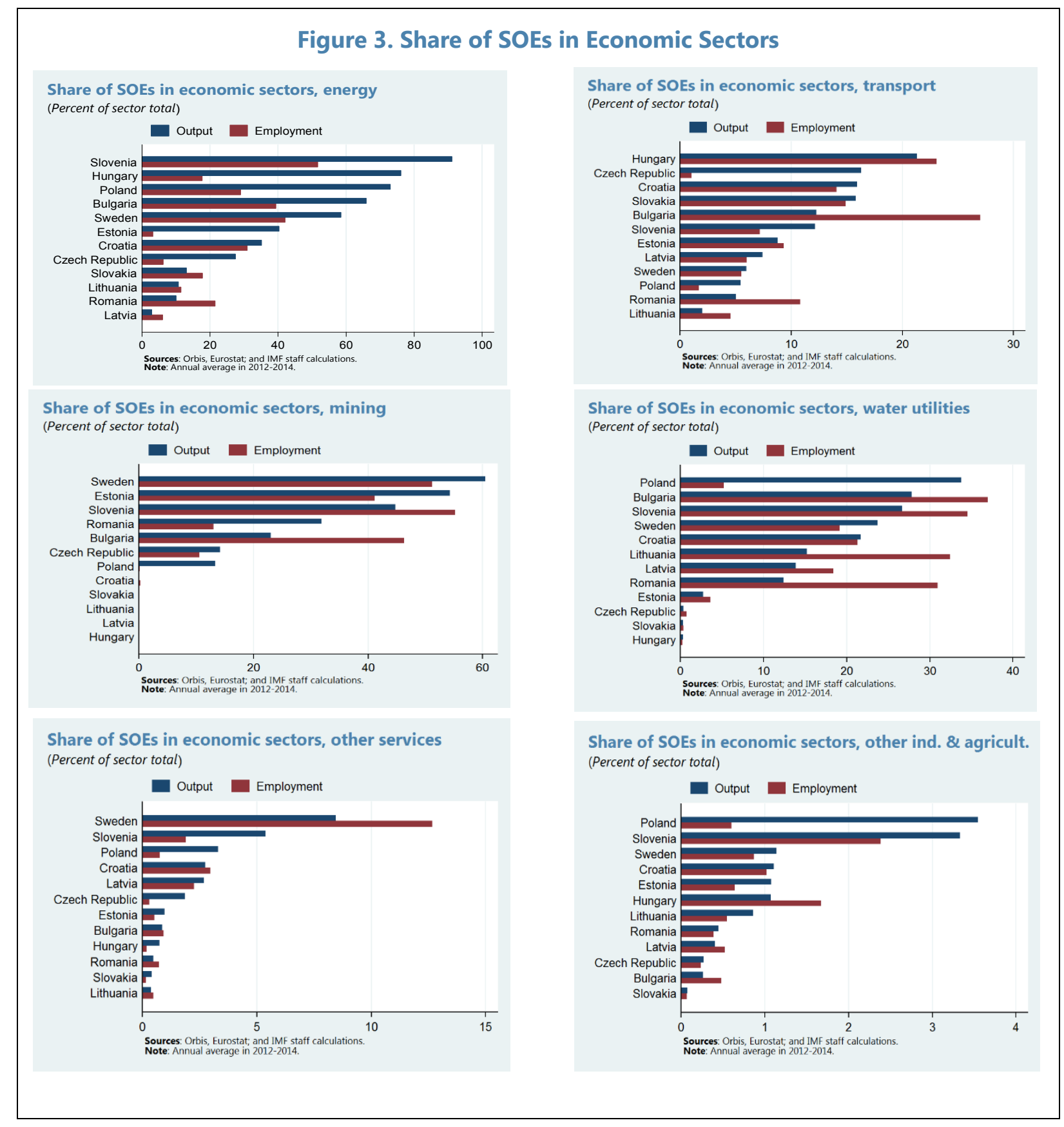

\section{SOE PERFORMANCE AND ECONOMIC RISKS}

This section addresses to SOEs' financial performance and ensuing risks. It first presents aggregate profits/losses, liabilities, profitability, as well as efficiency of capital and labor allocations. It then addresses output quality and discusses fiscal, financial and macroeconomic risks stemming from poor SOE performance. 


\section{A. Profits/Losses and Liabilities}

In some sectors, SOEs are heavily loss-making. Profits and losses before tax are aggregated across firms and by sectors, averaged over the period 2012-2014 and expressed in percent of GDP. In Southeastern Europe (SEE), large losses are recorded in the Bulgarian energy sector which are mainly due to the National Electricity Company and its structural tariff deficit. In Croatia, the transport sector stands out with significant losses. The stateowned automotive company is behind the losses in other industries in Slovenia. In Latvia, the losses in other services are caused by the bad bank which was established during the resolution of the country's financial crisis. In contrast, several sectors in other countries exhibit significant profits, for instance in the energy sectors of the Central and Eastern European (CEE) countries as well as Croatia and Estonia, and in Estonia's and Slovakia's transport sectors. In Sweden, the large profits in the services sector are mainly due to the gaming industry and public real estate companies.

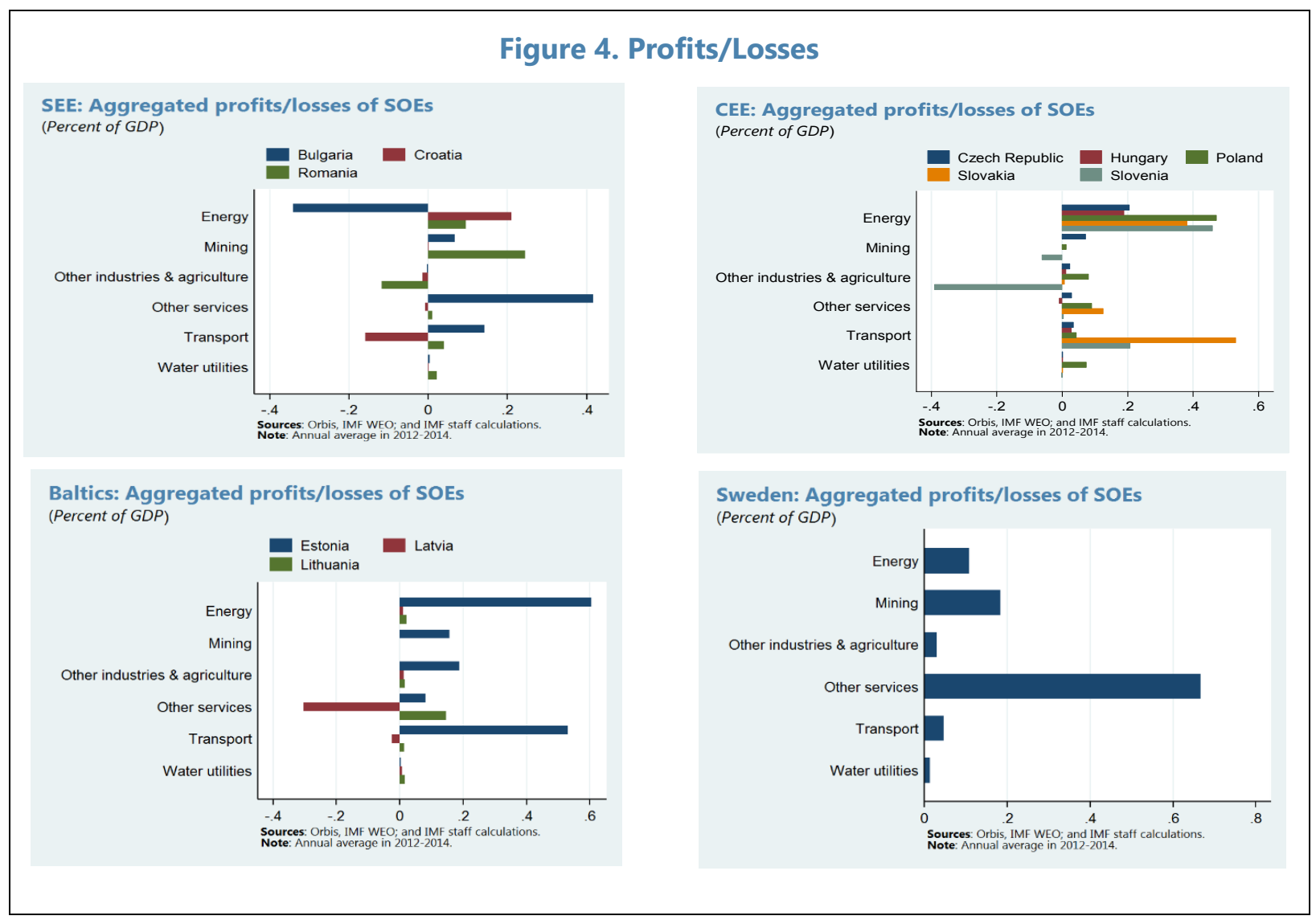

The accumulated liabilities of SOEs are partly very sizeable. The energy sectors in Bulgaria, Croatia, Estonia, and Slovenia show SOE debt ranging between 5 and 7 percent of GDP. The transport sector-largely the public railways - holds debt of around 9 percent of GDP in Slovenia and around 6 percent in Slovakia. The large liabilities of Croatia's other industries are due to the public motorway company. SOE debt in other services stands out in Latvia, again on account of the bad bank, and in Sweden where the telecom company and the real estate sector hold very large amounts of debt. 




\section{B. Profitability}

In most sectors, SOEs are less profitable than private firms. Firm profitability is measured by the return on equity (ROE), defined as the profits and losses before tax as a percentage of shareholders' equity. It hence indicates the ability of a company to generate profits with the money that shareholders have invested. In the vast majority of cases, SOEs are lagging behind private firms' profitability, with the notable exceptions of the Swedish and Estonian mining sectors as well as the Slovak services and industries. Across countries, Bulgaria, Romania and Poland tend to be among the lower-ranking countries, both in terms of ranked SOE profitability, and in terms of the gap between private-sector and SOE profitability, i.e. the difference between the blue and red bars in the charts. The comparison needs to be interpreted with some caution, as the profitability of certain SOEs might suffer from insufficient compensation for public service obligations and from regulated prices which, in the energy sector, can lead to structural tariff deficits. Moreover, caution is warranted given the averaging of very large numbers of private firms. However, the emerging big picture appears rather clear-cut, and resulting implications for policy and regulation are addressed in the section on SOE governance below. 


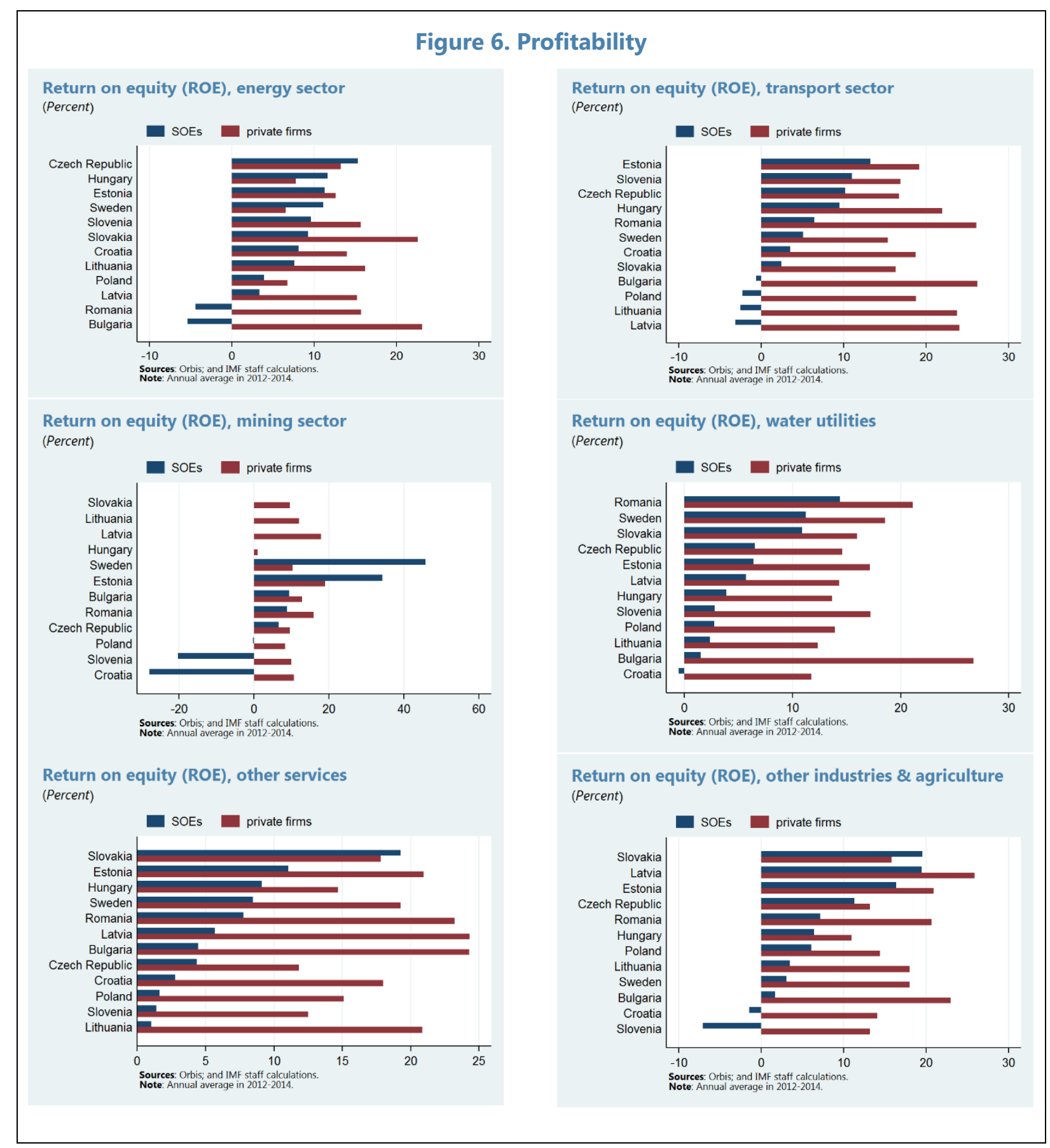

\section{Efficiency}

Allocative efficiency of capital of SOEs lags behind in many sectors. Efficiency of capital allocation is approximated by the return on capital employed (ROCE) which is the operating profit or loss before tax as a share of capital employed. This measure indicates the efficiency by which the sum of shareholders' equity and debt are deployed to generate profits. The 
transport sectors as well as other services display the largest gaps between the ROCE of SOEs and private firms in most countries, pointing to comparably inefficient capital allocation in SOEs of those sectors. In the energy and mining sectors, as well as in other industries, the picture is more nuanced, with some countries showing more capital efficient SOEs than private firms, such as the Czech Republic, Bulgaria (mining) and Slovakia (other industries).

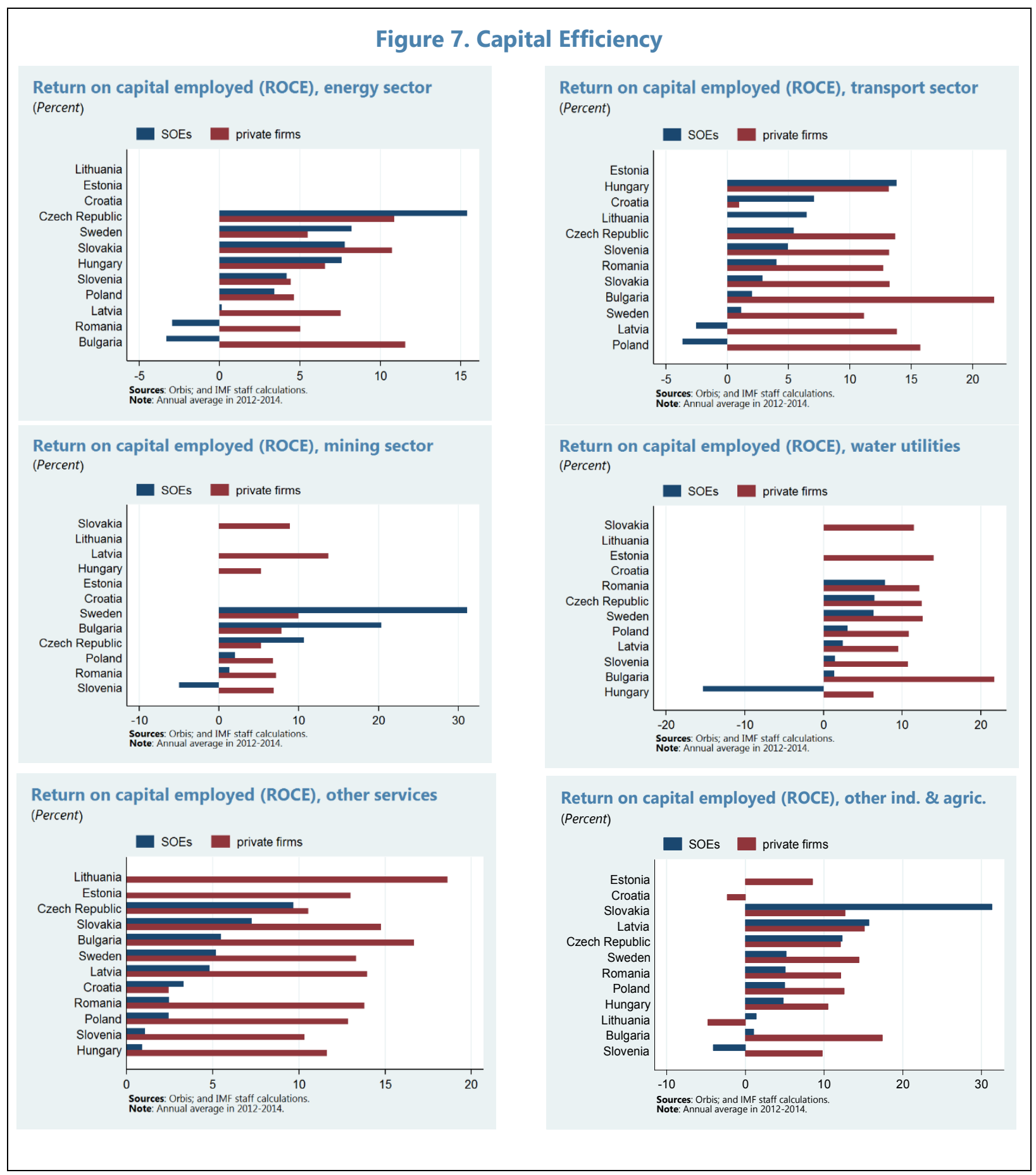


Allocative efficiency of labor scores relatively unfavorably in SOEs compared to private firms. This difference appears in higher average cost of labor per capita in SOEs than in private firms. In most countries and sectors, SOEs incur larger labor costs than private firms, partly substantially so. Cases of roughly equal labor cost in SOEs and private firms include the energy and transport sectors in Sweden, other services in Hungary and Poland, as well as other industries in Lithuania and Poland. Some extreme cases can be explained by small samples with notable outliers for this indicator, including the transport sector in Latvia which is driven by the national airline.

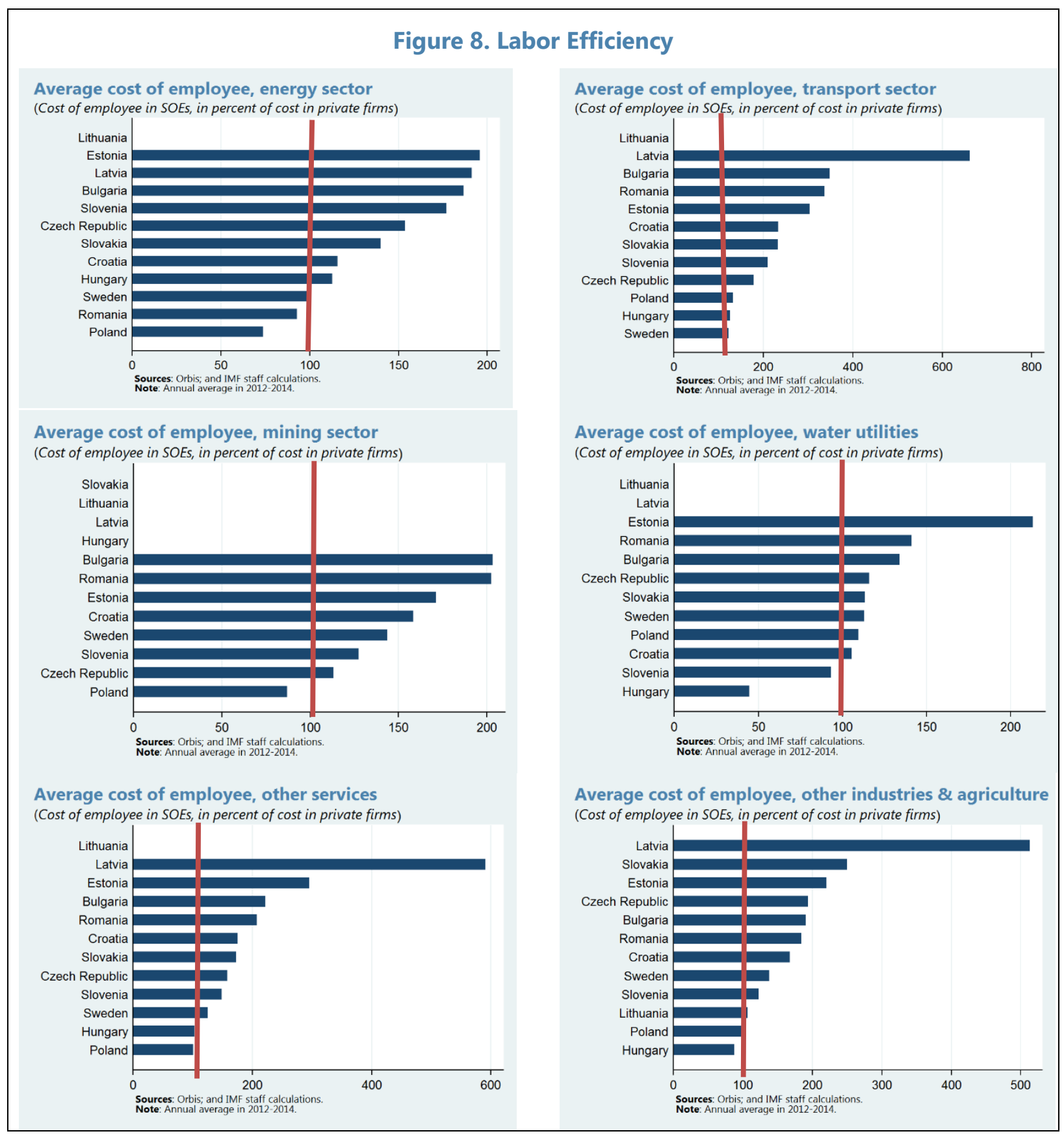




\section{Output Quality}

SOE-dominated infrastructure sectors deliver partly poor output quality. While no specific data for SOE output quality are available, the World Economic Forum's Global Competitiveness Indicators for infrastructure provide some inside in cross-country performance of those sectors which are partly heavily dominated by SOEs. Bulgaria and Romania exhibit particularly poor output quality, ranking at the bottom of the Emerging Europe sample in overall infrastructure, electricity supply and, when abstracting from the land-locked countries Czech Republic, Hungary, and Slovakia, also in port infrastructure. Next to Sweden, better performance is indicated for the Baltic countries, the Czech Republic, Slovakia and Slovenia.

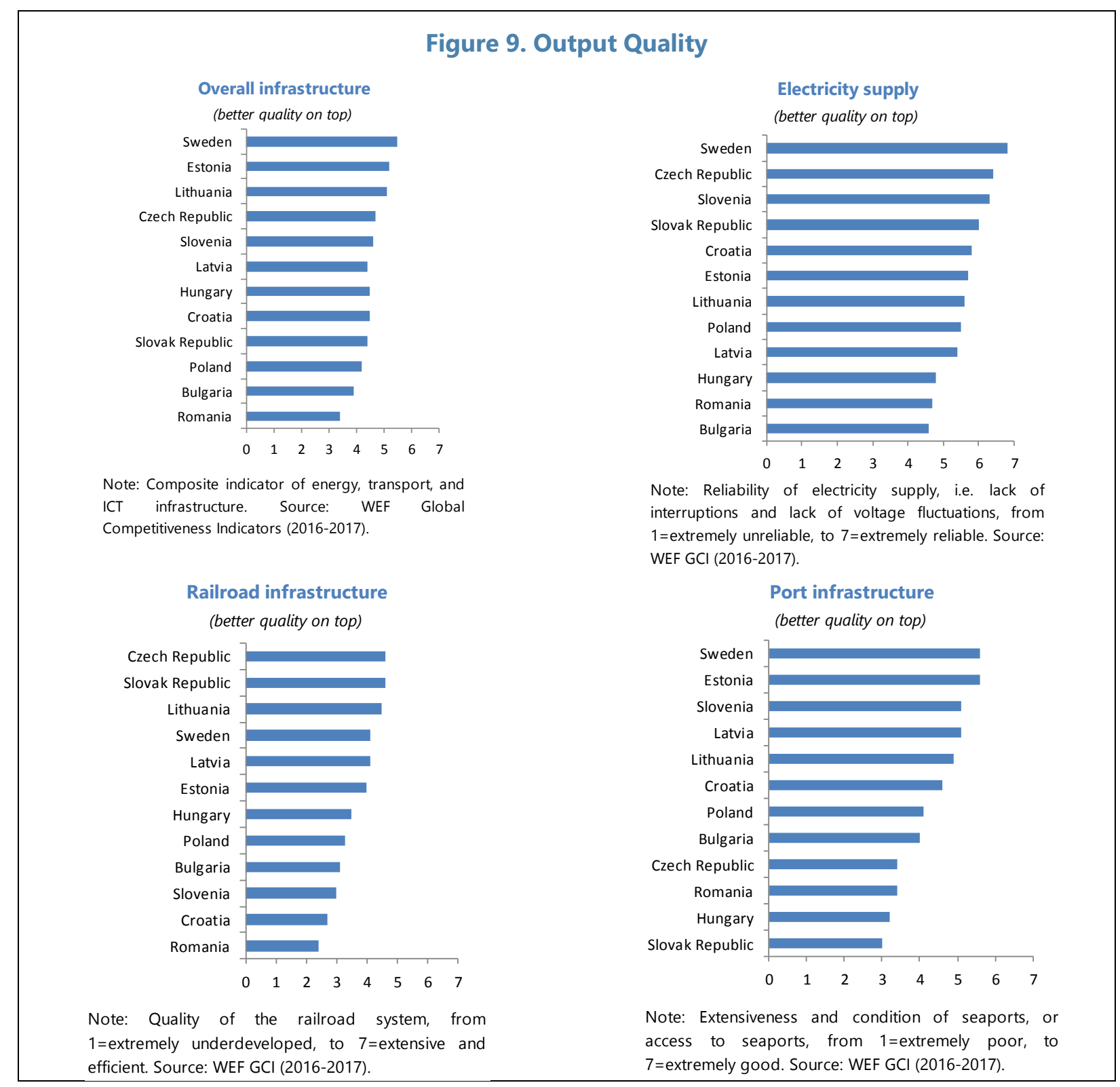




\section{E. Economic Risks of Poor SOE Performance}

Weak performance of SOEs carries macroeconomic risks. High indebtedness, feeble profitability, poor efficiency, and wanting output quality as shown in the preceding subsections can give rise to risks at the macro level. These risks can emerge via three main channels, namely (i) risks to public finances, mainly via contingent liabilities, (ii) risks to financial sector stability via state-owned banks, and (iii) risks to productivity and growth via spillovers from SOEs to other firms.

Fiscal risks arise with contingent liabilities on the back of excessive SOE indebtedness. Aggregate debt of SOEs classified outside of general government accounts represents contingent liabilities which might aggravate the risk profile of the public debt position. The degree of risk may either stem from the size of the contingent liabilities - as in the cases of Slovenia, Sweden and Poland - or from an elevated likelihood of materialization of even modest contingent liabilities. The latter might become relevant in cases where SOEs are largely exempt from insolvency regulations, such as in Bulgaria.

\section{Risks to financial sector stability may emanate from regulatory failures in the} face of sizeable state ownership of banks. In Slovenia, the state owned not only a sizeable portfolio of non-financial companies but also the three largest domestic banks and holds around 63 percent of the total banking sector's equity (IMF, 2016d; IMF, 2016e). After the first hit of the global financial crisis, Slovenia experienced another banking crisis in 2012-13 when the mostly state-owned banking system came under pressure and led the sovereign to lose market access. Cross-enterprise ownership structures with SOEs at their heart, and pervasive connected lending was believed to have amplified the crises. As a result, bankruptcies were wide-spread and mounting NPLs ate up bank capital (IMF, 2017b). Progress with privatization of Slovenian SOEs has been mixed so far, and the Slovenian experience highlights that corporate governance failures coupled with excessive state control of banks can result in interference with their lending, potentially leading to serious financial and macro stability risks.

Risks to productivity and growth emerge when SOE performance affects productivity also in other sectors of the economy. Recent World Bank analysis based on Bulgarian firmlevel data suggests that performance in SOE-dominated network service sectors has significant effects on firm productivity also in manufacturing and other downstream servicesector firms which rely on network service sector inputs (World Bank, 2015). The study measures network service sector performance by using EBRD Structural Change indicators, gauging reform progress in transition economies against the standards of advanced 
economies. The authors also test the impact of the presence of foreign service firms, the level of competition, and the extent to which service providers are also exporters on downstream firm productivity. Improvements in network service sector performance turns out to enhance downstream firm productivity particularly in the electricity sector, and also likely in the transport sector, although the analysis of the latter suffers from data shortages. Both sectors are typically dominated by SOEs in many Emerging European countries. Opening these sectors up to foreign investors, increasing competition and, to a lesser extent, promoting export activity among network sector firms, also leads to improved firm-level total factor productivity in downstream firms. In sum, the evidence suggests that the performance of SOE-dominated service sectors such as energy generates spillovers - positive or negativeon downstream firm productivity. Poor SOE performance hence carries risks to economywide productivity and growth, while tangible improvements in SOE performance has the potential to boost productivity across the economy as a whole.

\section{SOE GOVERNANCE}

This section turns to SOE governance as the foundation of SOE performance. It first presents the best-case SOE governance set-up as sketched by OECD guidelines. It then highlights the main shortcomings of SOE governance in Emerging Europe and summarizes three major lessons emerging from a comprehensive country-by-country review of recent SOE reforms.

\section{A. An Ideal SOE Governance Framework}

Good corporate governance is at the heart of healthy SOEs. Given their special role as providers of key public services, the effectiveness of SOEs has a strong impact on the welfare of citizens and on the competitiveness of the economy at large. As SOEs often operate with dual goals of economic market activity and public policy obligations, a functioning governance environment for SOEs is crucial. Well-designed governance structures are also needed to address the frequent challenge of undue hands-on and politically motivated ownership interference in SOEs.

The OECD guidelines on SOE governance provide an international benchmark of best practices. Agreed between OECD member states in 2005 and further developed in 2015, the guidelines are recommendations to governments towards efficient, transparent and accountable operation of SOEs. They aim at professionalizing the state as an owner, making SOEs operate with similar good practices as private enterprises, and ensuring competition between public and private firms at level playing field. Box 1 presents the overall guidelines in brief (OECD, 2015a). Due to their general relevance, these SOE guidelines constitute useful yardsticks also for those Emerging European countries which are currently not members of the OECD. 


\section{Box 1. OECD Guidelines on Corporate Governance of SOEs}

Rationales for state ownership: The state exercises the ownership of SOEs in the interest of the general public. It should carefully evaluate and disclose the objectives that justify state ownership and subject these to a recurrent review.

The state's role as an owner: The state should act as an informed and active owner, ensuring that the governance of SOEs is carried out in a transparent and accountable manner, with a high degree of professionalism and effectiveness.

SOES in the marketplace: Consistent with the rationale for state ownership, the legal and regulatory framework for SOEs should ensure a level playing field and fair competition in the marketplace when SOEs undertake economic activities.

Equitable treatment of shareholders: Where SOEs are listed or otherwise include non-state investors among their owners, the state and the enterprises should recognize the rights of all shareholders and ensure shareholders' equitable treatment and equal access to corporate information.

Stakeholder relations and responsible business: The state ownership policy should fully recognize SOEs' responsibilities towards stakeholders and request that SOEs report on their relations with stakeholders. It should make clear any expectations the state has in respect of responsible business conduct by SOEs.

Disclosure and transparency: SOEs should observe high standards of transparency and be subject to the same high quality accounting, disclosure, compliance and auditing standards as listed companies.

The responsibilities of boards: The boards of SOEs should have the necessary authority, competencies and objectivity to carry out their functions of strategic guidance and monitoring of management. They should act with integrity and be held accountable for their actions.

\section{B. SOE Governance Performance and Reforms in Emerging Europe}

\section{Qualitative governance indicators point to considerable variation across countries. The OECD's state control indicators for Emerging European countries gauges the insulation of SOEs from market discipline and the political interference in the management of SOEs. Bulgaria and Lithuania display the worst-possible ratings. The EBRD transition indicator on governance and enterprise restructuring measures the degree of hard budget constraints,}

\section{Figure 11. SOE Governance Performance}

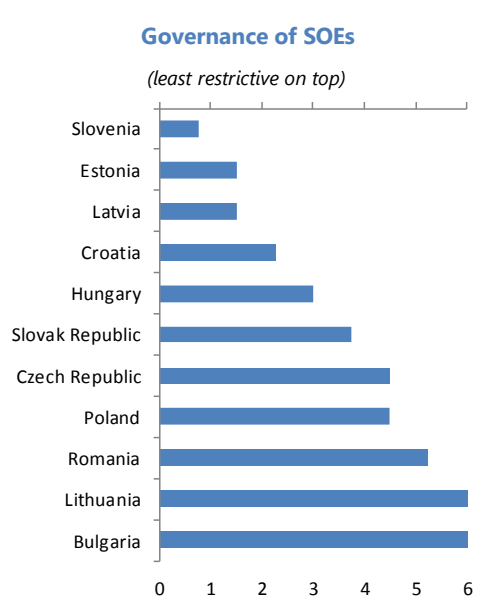

Note: Degree of insulation of SOEs from market discipline and degree of political interference in the management of SOEs. Source: OECD Product Market Regulation Indicators (2013).


Indicators (2014)

enforcement of bankruptcy legislation, competition and corporate governance. Again, Bulgaria scores worst among available countries, followed by Romania. However, these 
indicators should be interpreted with caution as they reflect only selected dimension of SOE governance, and in both cases, the latest vintages are already slightly dated.

Country-specific SOE governance challenges emerge in ownership policy, financial oversight, and board appointments. An extensive review of SOE governance challenges and reform efforts in Emerging European countries included in this study points to three main areas of concern. Figure 12 shows these challenges and the resulting risks in overview.

- Ownership policy. At the strategic level, the rationale for state ownership is rarely specified clearly, partly as a legacy of inconsistent post-transition privatization procedures. The objectives of SOEs are often not unequivocally defined and spelt out. Legal provisions concerning SOEs tend to be unclear and opaque. As a result, the responsibilities for SOEs are typically fragmented and without clear reporting lines among government ministries and agencies.

- Financial oversight. At the more specific level of financial oversight, there are either no dedicated oversight teams in place, or they tend to be understaffed and not endowed with a sufficiently rigorous mandate. Effective financial oversight is often hampered by the absence or vagueness of SOE performance targets. Even if such targets are in place, compliance is often not monitored with adequate scrutiny, or failure to comply is not sanctioned with deterring consequences. Dividend policies are in many cases erratic and lack predictability.

- Board appointments. Zooming into corporate governance at firm level, many SOEs suffer from political board appointments without transparent and competitive selection procedures. Frequent replacements hamper efficient board functioning. Private-sector expertise, international experience, and independent board members are often absent. In many cases, remuneration is not fully transparent nor performance-based.

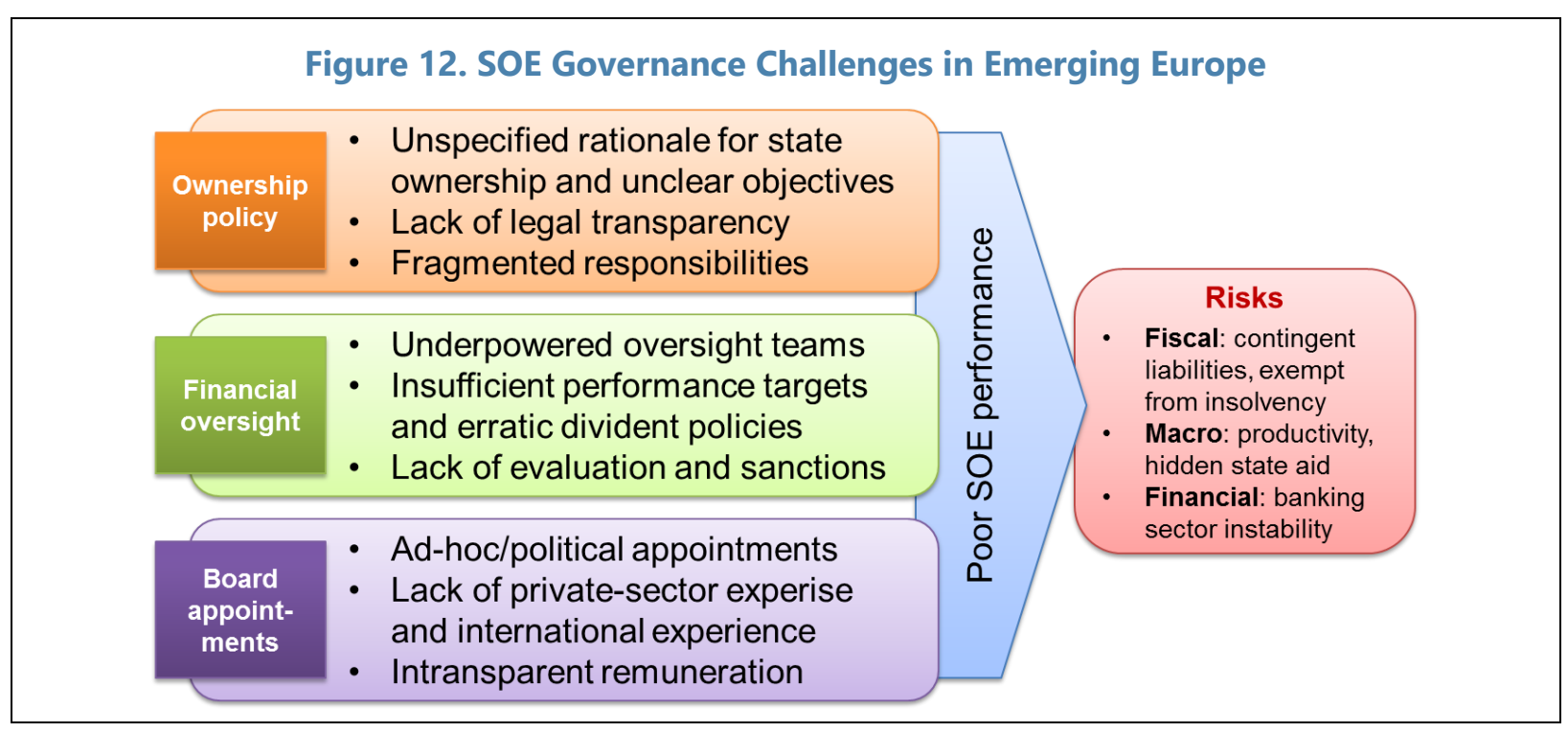


Several countries have undertaken SOE reform while others are lagging behind. The country-specific review of reform experiences is detailed in the Annex. Three major lessons emerge.

\section{Lesson \#1: Flesh out a consistent ownership policy}

A clear institutional basis is the foundation of a strong ownership policy. This could be a dedicated SOE framework law, or a high-level political document referencing and synthesizing the elements of policies, laws, and regulations applicable to SOEs. It should specify the rationale for state ownership, outline well-defined policy objectives, and lay out a coherent strategy for exercising the state's SOE ownership function. Transparent ownership structures and clear privatization strategies, notably for the banking sector, can reduce financial stability risks. Latvia's State Administration Structure Law stipulates the rationale in cases of market failure, natural monopoly, strategically important sectors and overriding public interest (OECD 2015b). Lithuania's Ownership Guidelines indicate profit maximization, national strategic interests as well as social purposes as key SOE policy objectives (OECD 2015c). A regular review of state ownership should make the case for divestment of state assets if deemed no longer in line with state ownership objectives. Estonia and Sweden carry out such a review on an annual basis (OECD, 2011; Regeringskansliet, 2015).

The roles and responsibilities of various government bodies should be clearly specified and ring-fenced to avoid inconsistency and overlap. Notably, the choice between a centralized vs. decentralized or hybrid ownership models must be made on solid grounds. The OECD recommends to exercise SOE ownership rights in one dedicated, accountable entity within the government, rather than keeping SOE responsibility primarily at the level of line ministries or other agencies. The benefit of the central approach is to ensure consistency and allow for concentrating relevant experts on key issues in one place. Experience in Bulgaria and Romania suggests that countries with weaker institutional environments are at greater risk of losses to welfare, productivity and growth due to cronyism if they operate a decentralized governance model that leaves SOE management in the hands of line ministries with little coordination across government entities (IMF 2016b). These countries are likely to fare better with a centralized model, provided the central ownership entity is subject to effective accountability. Slovenia has established a centralized holding company in charge of managing and divesting state assets (European Commission, 2015c). However, the example of Sweden shows that a robust institutional environment also allows for well-functioning decentralized or hybrid models (European Commission, 2016a; Regeringskansliet, 2015).

Ownership and policy functions should be clearly separated. Ownership functions, e.g. to pursue value maximization, should be kept distinct from policy functions, such as sectoral regulation, to avoid conflict of interest and political patronage and hence reduce the risk of fiscal excess and efficiency loss. This separation is generally facilitated by adopting the centralized ownership model. Slovenia has incorporated this separation in its new corporate governance code for SOEs (European Commission, 2015c). Also Romania has made efforts towards this end but their effectiveness remains limited as long as the ownership set-up continues to be fragmented (Marrez, 2015). 
The competition authority needs a strong mandate to ensure a level playing field. Putting SOEs on equal footing with private firms would benefit cross-sector productivity and, by abolishing insolvency exemptions, reduce also fiscal risks. The competition authority should be empowered to reach also the municipal level. Sweden's competition authority can take municipalities to court in cases where the set-up of SOEs is believed to constitute an unwarranted constraint to competitive markets in relation to private firms (European Commission, 2016a).

\section{Lesson \#2: Give teeth to financial oversight}

A well-powered SOE oversight unit should be established or upgraded. Financial oversight focuses on specific SOE performance monitoring and is hence distinct from the general ownership policy. As a first step, a dedicated financial oversight unit should collect and synthesize SOE financial information on a regular basis and build a publicly-accessible database which also includes SOEs at sub-national levels. As a second step, the oversight unit should analyze risks to fiscal, financial, and macro stability emanating from potential SOE underperformance. It should also develop strategies for mitigating these risks and publish its findings in regular reports which ensure public accountability and feed these proposals into the political process to inform any potential fiscal implications beyond party lines. The oversight units are often best-placed in the Ministry of Finance, but depending on a country's institutional structure, they can also reside in other government entities with the respective skill resources. In Estonia, an oversight unit within the Ministry of Finance monitors financial accounts and publishes a consolidated annual report (OECD, 2011). In Sweden, this role is assigned to a unit within the Ministry for Enterprise and Innovation; however, only central-government SOEs are covered (Regeringskansliet, 2015). Lithuania operates a coordination unit in its State Property Fund (European Commission, 2015b).

Clearly defined performance targets should be put in place and effectively monitored. These targets are preferably based on rates of return or capital structures, as is the case in Sweden, Latvia, Lithuania and Slovenia (Regeringskansliet, 2015; OECD, 2015b; OECD, 2015c; European Commission, 2017f). On the contrary, performance targets that relate to sales volumes or employment, like in Bulgaria, can have counter-productive effects as they tend to serve industrial or labor market policy goals, rather than value maximization (IMF, 2016b). Performance benchmarking with private and foreign companies can further inform the monitoring process towards better resource allocation efficiency. Compliance with the performance targets should be closely monitored by the oversight unit or in delegated entities. Non-compliance should be followed by sanctions of varying severity, ranging from additional reporting requirements to administrative measures imposed on SOE boards (IMF, 2016a). Among OECD countries, Korea applies a particularly informative and rigorous SOE monitoring system, including customer satisfaction surveys and index-based evaluations which are seen as key factors for the exemplary efficiency and performance of Korea's SOEs (Park et al. 2016).

Dividend policies should be predictable and balanced. They should facilitate a stable planning framework for the company's long-term investment while ensuring an adequate capital return for the state as an owner. In Bulgaria, the Czech Republic, Estonia and 
Hungary, dividend requirements are determined on an ad-hoc basis, partly taking into account the financial state of companies, and are sometimes guided more by government budget needs than SOE profitability. Poland applies broad guidelines stipulating that annual dividend decisions should be guided by the need to recover prior losses, long-term investment strategies, privatization, and firm indebtedness. The dividend levels are determined in relation to rate-of-return indicators and liquidity ratios. In Lithuania, explicit dividend ratios apply, amounting to at least 7 percent of equity and at most 80 percent of company profits for limited liability firms while statutory corporations are expected to pay out 50 percent of annual profits. Slovenia's general dividend policy foresees an annual payout of at least one third of net profits. In other countries, including Australia and the Netherlands, dividend payments are explicitly linked to achieving a desired capital structure, reflected by a certain target credit rating (OECD 2014b). While that level of sophistication might be excessive for Emerging European countries, it seems advisable to adopt an intermediate degree of formalization to make dividend policies work better for SOEs and the state.

\section{Lesson \#3: Make SOE boards more professional}

The role of SOE boards should be unequivocally defined and founded in legislation. Endowed with a clear mandate, boards should be enabled to exercise their operational functions independently and without undue state intervention. Transparency measures, such as reporting requirements, should promote accountability. Board performance should be evaluated on an annual basis, as is the case in the Czech Republic and Sweden (OECD, 2013; Regeringskansliet, 2015).

The nomination process for board members should be transparent and skill-based. Appointments should rely on competitive selection procedures based on competence, not on political affiliation, and include independent board members. Croatia and Romania have made efforts to depoliticize SOE boards by improving transparency of selection procedures, sharpening qualification requirements and involving external contractors (European Commission, 2016a; Marrez, 2015). However, the independence of external staffing agencies is cannot always be guaranteed if they depend on government funding. Candidates should ideally possess private-sector expertise and international experience. Estonia requires board members to come equally from the private and public sectors to secure more private-sector expertise (OECD, 2013). Excessively frequent changes, as report in Bulgaria, should be avoided (Park et al., 2016).

Remuneration policies should be clear and balanced. The trade-off between attracting qualified professionals and ensuring long-term company interests needs to be addressed Avoiding excessive remuneration helps to reduce fiscal risks. Remuneration should ideally be linked to performance. Sweden applies guidelines for reasonable and competitive remuneration of senior executives in agreement with shareholders. In Hungary, remuneration limits in relation to the minimum wage are in place (OECD, 2013). 


\section{Conclusion}

SOE performance in Emerging Europe shows a mixed picture. SOEs play an important role in the economies of Emerging Europe, notably in network sectors. Compared to private firms, the profitability and efficiency of resource allocation in SOEs largely lag behind, as evidenced by sizeable gaps in return on equity and return on capital employed, as well as unfavorable relative cost of employees. Large cross-country variation shows that some countries exhibit worse SOE performance than others.

Poor SOE performance creates risks to fiscal, financial, and macro stability. In cases of sizeable contingent liabilities, or when moderate contingent liabilities are more likely to materialize on the back of insolvency exemptions, public finances can come under pressure. Financial instability can be accelerated in case of large-scale state ownership of banks coupled with opaque cross-ownership structures and regulatory failures. Spillover of weak productivity to downstream firms reflects the wider macro risk of poor SOE performance.

SOE governance challenges should be addressed by comprehensive reforms. Reviewing SOE governance challenges and recent reform experiences country-by-country reveals a mixed bag of "good, bad and ugly" practices. While some countries, such as Slovenia and Lithuania, have advanced their SOE governance frameworks in recent years, others are still at the early stage of SOE reform, such as Bulgaria. The emerging lessons point to a need to (i) clearly define the high-level ownership policy by specifying and regularly reviewing the case of state ownership case-by-case, assigning distinct responsibilities to government entities, and ideally exercising the ownership function in a centralized manner as long as overall institutional quality remains weak; (ii) give teeth to financial oversight teams to effectively implement and monitor financial performance targets; and (iii) professionalize SOE boards by ensuring competitive selection procedures based on skill and experience, as well as transparent and merit-based remuneration. Overall, SOE reform efforts show that the devil is in the details, and even strong de jure frameworks are challenged by implementation failures. Achieving a sustainable and healthy SOE landscape will require perseverance and stamina over time. 


\section{AnNeX}

Table A1. Recent SOE Reform Experience in Emerging Europe and Sweden

\begin{tabular}{|c|c|c|c|}
\hline & Ownership policy & Financial oversight & SOE boards \\
\hline Bulgaria & $\begin{array}{l}\text { - No clear rationale nor } \\
\text { strategy for state ownership } \\
\text { - Fragmented framework: line } \\
\text { ministries in charge, no } \\
\text { effective coordination } \\
\text { - SOE framework law failed in } \\
2013, \text { new draft underway }\end{array}$ & $\begin{array}{l}\text { - Publication of quarterly SOE } \\
\text { statements but no } \\
\text { systematic risk assessment } \\
\text { - Targets and monitoring with } \\
\text { line ministries, falling short } \\
\text { of international practices } \\
\text { - No clear lines of } \\
\text { accountability for fiscal risk }\end{array}$ & $\begin{array}{l}\text { - Competitive selections } \\
\text { possible but unusual } \\
\text { - Absence of value- } \\
\text { maximizing remuneration } \\
\text { - Frequent change and } \\
\text { political intervention leading } \\
\text { to inappropriate } \\
\text { qualification and experience }\end{array}$ \\
\hline Croatia & $\begin{array}{l}\text { - Definition of strategic SOEs } \\
\text { vs. SOEs for privatization } \\
\text { - Ownership decentralized } \\
\text { - Privatizations advanced at } \\
\text { slow pace and partly failed }\end{array}$ & $\begin{array}{l}\text { - Attempts to strengthen } \\
\text { monitoring framework } \\
\text { - Limited supervision, no } \\
\text { medium-term performance } \\
\text { benchmarks }\end{array}$ & $\begin{array}{l}\text { - New selection framework to } \\
\text { improve qualifications and } \\
\text { to allow for private-sector } \\
\text { candidates } \\
\text { - Even external recruitment } \\
\text { firms not fully independent }\end{array}$ \\
\hline Czech Republic & $\begin{array}{l}\text { - Social, strategic and public } \\
\text { beneficial objectives } \\
\text { - Ownership role transferred } \\
\text { from privatization agency to } \\
\text { MoF while line ministries } \\
\text { keep operational control }\end{array}$ & $\begin{array}{l}\text { - Financial performance } \\
\text { supervised by MoF }\end{array}$ & $\begin{array}{l}\text { - Adoption of principles for } \\
\text { remuneration structures } \\
\text { - New transparency and } \\
\text { accountability mechanisms } \\
\text { - Nominations require } \\
\text { professional qualifications } \\
\text { - External audit assessments } \\
\text { of board performance }\end{array}$ \\
\hline Estonia & $\begin{array}{l}\text { - Objectives: public purpose } \\
\text { and earning revenue } \\
\text { - Ownership and regulation } \\
\text { functions separated but no } \\
\text { formal ownership policy } \\
\text { document }\end{array}$ & $\begin{array}{l}\text { - MoF coordination unit to } \\
\text { monitor financial accounts } \\
\text { and publish a consolidated } \\
\text { annual report } \\
\text { - Internal audit functions only } \\
\text { beyond a certain size }\end{array}$ & $\begin{array}{l}\text { Direct instructions from } \\
\text { ministers to SOE directors } \\
\text { abolished } \\
\text { - Board members equally } \\
\text { from private and public } \\
\text { sectors }\end{array}$ \\
\hline Hungary & $\begin{array}{l}\text { - State assets act regulates } \\
\text { management of SOEs } \\
\text { - Objectives: long-term } \\
\text { management, value creation } \\
\text { - State holding company } \\
\text { under Min. of Development } \\
\text { but also other govt. bodies }\end{array}$ & $\begin{array}{l}\text { Inter-ministerial council } \\
\text { established to oversee } \\
\text { holding company and SOE } \\
\text { management }\end{array}$ & $\begin{array}{l}\text { Qualification requirements } \\
\text { for supervisory boards } \\
\text { - Public and independent } \\
\text { representatives but no } \\
\text { explicit policy preference } \\
\text { - Remuneration limits in } \\
\text { relation to minimum wage }\end{array}$ \\
\hline Latvia & $\begin{array}{l}\text { - New SOE law } \\
\text { - Rationales for ownership: } \\
\text { market failure, natural } \\
\text { monopoly, strategic sectors } \\
\text { - Initial ambition for central } \\
\text { holding structure watered } \\
\text { down }\end{array}$ & $\begin{array}{l}\text { - Coordination institution } \\
\text { monitoring and assessing } \\
\text { SOE performance based on } \\
\text { rate-of-return criteria } \\
\text { - Municipal SOEs not included }\end{array}$ & $\begin{array}{l}\text { - Reintroduction of boards of } \\
\text { directors with appropriate } \\
\text { professional background } \\
\text { - Nomination/appointment } \\
\text { process unclear } \\
\text { - Remuneration regulations } \\
\text { set by the Cabinet }\end{array}$ \\
\hline Lithuania & $\begin{array}{l}\text { - Ownership guideline: profit- } \\
\text { maximization, strategic } \\
\text { interest, social goals } \\
\text { - Specified responsibilities of } \\
\text { state ownership entities } \\
\text { - Separation of ownership and } \\
\text { policy functions } \\
\text { - Failed to set up holding firm }\end{array}$ & $\begin{array}{l}\text { - Performance targets based } \\
\text { on return on equity } \\
\text { - Monitoring mechanism in } \\
\text { place } \\
\text { - Dividend policy specified by } \\
\text { firm statute } \\
\text { - Coordination unit in the } \\
\text { State Property Fund }\end{array}$ & $\begin{array}{l}\text { - Criteria for nomination and } \\
\text { appointment } \\
\text { - Database of potential board } \\
\text { members } \\
\text { - At least } 1 / 3 \text { of board } \\
\text { members to be independent } \\
\text { - Implementation and } \\
\text { autonomy to be improved }\end{array}$ \\
\hline
\end{tabular}


Poland

Romania

Slovenia

Sweden
- Legislation to separate ownership from regulation and to promote value creation and competition while keeping state control in strategic cases

- Privatizations but limited shift of control; recent push to increase role of SOEs

- Specified public service obligations

- Separation of ownership and policy functions

- Ownership set-up remains fragmented

- Separation of ownership and policy functions

- Consolidation of ownership and management by holding company and bad bank

- Long-term strategy for state assets and divestment classification

- Detailed ownership policy

- Value generation and public service assignment

- Case for public ownership reviewed annually

- Competition authority can take municipalities to court
- Oversight delegated by Prime Minister's Office to line ministries

- Dividends determined in relation to rate-of-return indicators and liquidity ratios

- MoF unit tasked with oversight but underpowered

- Strengthened performance monitoring at MoF

- Enhanced transparency on financial information and related-party transactions

- Overall profitability target: $8 \%$ return-on-equity by 2020

- Individual performance indicators for each SOE

- Dividend policy: annual payout of at least $1 / 3$ of net profits

- Annual aggregate SOE report (central government)

- Firm-specific targets and performance tracking

- Same reporting transparency as listed firms

- Dividend policy linked to optimal capital structure
- Possibility of open competition and recruitment consultants but direct appointments remain possible

- Appointment subject to opinion by special council in PM Office

- Amended legislation for more transparent and professional selections to de-politicize boards

- Contracting of selection process to external advisor in case of large companies

- Implementation challenging

- Improved transparency of remuneration and bonuses

- Commitment to assessing SOE management performance based on objective criteria

- Nomination: committees establish needs-based recruitment profiles

- Collective govt. decision

- Guidelines for reasonable, competitive remuneration

- Annual evaluations and selfevaluation 


\section{REFERENCES}

European Commission, 2017a, Country Report Croatia 2017, Commission Staff Working Document, European Commission, Brussels.

European Commission, 2017b, Country Report Latvia 2017, Commission Staff Working Document, European Commission, Brussels.

European Commission, 2017c, Country Report Lithuania 2017, Commission Staff Working Document, European Commission, Brussels.

European Commission, 2017d, Country Report Poland 2017, Commission Staff Working Document, European Commission, Brussels.

European Commission, 2017e, Country Report Romania 2017, Commission Staff Working Document, European Commission, Brussels.

European Commission, 2017f, Country Report Slovenia 2017, Commission Staff Working Document, European Commission, Brussels.

European Commission, 2016. "State-Owned Enterprises in the EU: Lessons Learnt and Ways Forward in a Post-Crisis Context", European Economy Institutional Paper 031, European Commission, Brussels.

European Commission, 2016a, Country Report Croatia 2016, Commission Staff Working Document, European Commission, Brussels.

European Commission, 2016b, Country Report Slovenia 2016, Commission Staff Working Document, European Commission, Brussels.

European Commission, 2015a, Country Report Croatia 2015, Commission Staff Working Document, European Commission, Brussels.

European Commission, 2015b, Country Report Lithuania 2015, Commission Staff Working Document, European Commission, Brussels.

European Commission, 2015c, Country Report Slovenia 2015, Commission Staff Working Document, European Commission, Brussels.

Georgieva, S. and D. M. Riquelme, 2013. "Slovenia: State-Owned and State-Controlled Enterprises" ECFIN Country Focus 10(3), European Commission, Brussels.

IMF, 2017a. "Bulgaria. Oversight and Management of State-Owned Enterprises" IMF

Technical Assistance Report, International Monetary Fund, Washington. 
IMF, 2017b. "Slovenia 2017 Article IV Consultation - Staff Report.” IMF Country Report No. 17/125, International Monetary Fund, Washington.

IMF, 2016a. "How to Improve the Financial Oversight of Public Corporations" IMF How To Notes 5, International Monetary Fund, Washington.

IMF, 2016b. "Bulgaria-State-Owned Enterprises in Regional Perspective" IMF Country Report No. 16/345, International Monetary Fund, Washington.

IMF, 2016c. "Hungary 2016 Article IV Consultation - Staff Report.” IMF Country Report No. 16/107, International Monetary Fund, Washington.

IMF, 2016d. "Slovenia 2016 Article IV Consultation - Staff Report.” IMF Country Report No. 16/122, International Monetary Fund, Washington.

IMF, 2016e. "Slovenia-Financial Sector Development Issues and Prospects" IMF Country Report No. 16/345, International Monetary Fund, Washington.

IMF, 2015a. "Croatia 2015 Article IV Consultation - Staff Report.” IMF Country Report No. 15/163, International Monetary Fund, Washington.

IMF, 2015b. "Hungary 2015 Article IV Consultation - Staff Report.” IMF Country Report No. 15/92, International Monetary Fund, Washington.

IMF, 2015c. "Romanian State-Owned Enterprises: Challenges and Reform Priorities" IMF Country Report No. 15/79, International Monetary Fund, Washington.

IMF, 2012. "Poland 2012 Article IV Consultation - Staff Report.” IMF Country Report No. 12/162, International Monetary Fund, Washington.

IMF, 2012. "Romania-Boosting Growth through Reform of State-Owned Enterprises" IMF Country Report No. 12/291, International Monetary Fund, Washington.

Marrez, H., 2015. "The Role of State-Owned Enterprises in Romania” ECFIN Country Focus 12(1), European Commission, Brussels.

OECD, 2016a. "Broadening the Ownership of State-Owned Enterprises", OECD Publishing, Organization for Economic Co-operation and Development, Paris.

OECD, 2016b. "State-Owned Enterprises as Global Competitors", OECD Publishing, Organization for Economic Co-operation and Development, Paris.

OECD, 2015a. "Guidelines on Corporate Governance of State-Owned Enterprises", 2015 Edition, OECD Publishing, Organization for Economic Co-operation and Development, Paris. 
OECD, 2015b. "Review of the Corporate Governance of State-Owned Enterprises, Latvia", OECD Publishing, Organization for Economic Co-operation and Development, Paris.

OECD, 2015c. "Review of the Corporate Governance of State-Owned Enterprises, Lithuania", OECD Publishing, Organization for Economic Co-operation and Development, Paris.

OECD, 2015d. "State-Owned Enterprise Governance. A Stocktaking of Government Rationales for Enterprise Ownership" OECD Publishing, Organization for Economic Co-operation and Development, Paris.

OECD, 2015e. "The Size and Sectoral Distributions of SOEs in OECD and Partner Countries", OECD Publishing, Organization for Economic Co-operation and Development, Paris.

OECD, 2014a. "Boards of Directors of State-Owned Enterprises", OECD Publishing, Organization for Economic Co-operation and Development, Paris.

OECD, 2014b. "Financing State-Owned Enterprises", OECD Publishing, Organization for Economic Co-operation and Development, Paris.

OECD, 2013. "Boards of Directors of State-Owned Enterprises", OECD Publishing, Organization for Economic Co-operation and Development, Paris.

OECD, 2011. "State-Owned Enterprise Governance Reform", OECD Publishing, Organization for Economic Co-operation and Development, Paris.

Park, J., D. N. Bobeva-Filipova, M. A. Dimitrov, S. V. Keremidchiev, P. D. Tchipev, 2016, Governance Innovation for SOEs in Bulgaria: Based on Korean Experience in 31 questions, In: "2015/16 Knowledge Sharing Program with Bulgaria: Policy Studies for Bulgaria's Sustainable Growth - Enhancing Innovation and Accountability", Ministry of Strategy and Finance, Republic of Korea, Seoul.

Regeringskansliet, 2015. “Annual Report State-Owned Enterprises”, Ministry for Enterprise and Innovation, Sweden, Stockholm.

World Bank, 2015. "Productivity in Bulgaria: Trends and Options" Document of the World Bank, Washington. 